\title{
Air Transport and Tourism in Indonesia
}

\section{Ir. Prasadja Ricardianto, ${ }^{1}$ Dr.Gunawan Djajaputra ${ }^{2}$ and Prof.Dr.Martono ${ }^{3}$}

\section{Introduction}

Air Transportation is the easiest and most comfortable means of travel in Indonesia. Air service are available to all provincial district capitals and other remote areas operated by an Indonesian airlines. There are at least 27 domestic scheduled airlines ${ }^{4}$ and at least 8 (eight) charter airlines. ${ }^{5}$ Garuda Indonesia, the national flag air carrier, operates on both international and domestic routes. It serves 33 cities including all the provincial capital. It has several daily flights from Jakarta to destination of commercial and touristic importance. ${ }^{6}$ In addition, it also operates shuttle flight to Surabaya and Semarang several time a day. Special for visitors Garuda Indonesia has introduced Visit Indonesia Air Passes which offers special fares on its domestic flights. ${ }^{7}$ Bali is served by Garuda and Qantas and since 1986 Garuda initiated joint services with SIA, MAS, Cathay Pacific, JAL, Silk Air, China Airlines, Thai Airways International (TAI), Continental Airlines and Royal Brunei for direct flights to Bali from Singapore, Kuala Lumpur, Bangkok, Brunei Darussalam, Guatemala, Hong Kong, Nagoya, Osaka, Tokyo, and Taipei and other service from Amsterdam, through Vienna and Abudhabi to Medan and Bali, offering easier accessibility and overflying Jakarta. ${ }^{8}$

\section{Air Transport Industry and Tourism}

Air transport industry and tourism are complemented each other. Tourism depends on transportation to bring visitors, whilst the transportation industry depends on tourism to generate demand for its services. The growth in tourism industry directly reflects onto the air transportation. Over the last 25 years, the number of international tourists has more than doubled. The expansion of international tourism has a large impact on the discipline of transport geography. Transport is the cause and the effect of the growth of tourism. To start with, the improved facilities have stimulated tourism, and the expansion of tourism has stimulated transport. Accessibility is the main function behind the basics of tourism transport. In order to access the areas that are mainly aimed, tourists will use any transportation mode. However, air transport is the main mode for international tourism. Air transport plays a dominant role in inter-regional movements of tourists, which normally entails travel over long-distance. Growth rates of international air traffic are pegged with growth rates of international tourism. Attractive package tours, competitive airfare attract more and more tourist day by days, therefore both the industry is expanding rapidly

The connectivity provided by international air transport facilities the fast-growing global tourism industry. It is estimated that over half of international tourists travel to their destination by air. Tourism makes a major contribution to the global economy of State. It directly contributed US\$2.2 trillion to world Gross

\footnotetext{
${ }^{1}$ Prasadja Ricardianto, Ir.(University of Trisakti), MM (IPWI Jakarta), previously served as the member of the Management Project of Ciputra Development. He has written extensively about Transportation, Tourism, Management Project in Indonesia, Head of The Center for Research and Community Service of STMT-Trisakti, Editor Board of Journal of Transportation and Logistic Management of STMTTrisakti, Lecturer of School's Transportation of Trisakti (STMT-Trisakti).

${ }^{2}$ Lecturer of Law Faculty of the Tarumanagara University

${ }^{3}$ Prof.Dr.H.K.Martono,S.H.(University of Indonesia), L.L.M (McGill), Ph.D (Diponegoro, University) previously served as the chief of the legal division of the Directorate General of Civil Aviation, at Indonesias Ministry of Communications. He has written extensively about aviation law and regulations in Indonesia and was parliamentary resource person for when Indonesia was drafting the Civil Aviation Act of 2009, Lecturer of the Law Faculty of University of Tarumanagara, the Moslem Univeristy of Jakarta and the University of Suryadarma.

${ }^{4}$.Airfast Indonesia, Airmark Indonesia, Air Regional, Aviastar (Inodnesia), Batik Air, Citilink, Dimonim Air, Garuda Indonesia, Indonesia Air Asia, Indonesia AirAsia X, Indonesia Air Transport (IAT), Jhonlin Air Transport, Kalimantan Air Services, Kalstar Aviation, Kaltim Airlines, Lion Air, NAM Air, Pelita Air Services, Sky Aviation, Sriwijaya Air, Susi Air, Transnusa Air Services, Travira Air, Trigana Air Services, Wing Air and Xpress Air.

${ }^{5}$.Air Born Indonesia, Eastindo, Gatari Air Services, Mimika Air, Nusantara Air Charter, Nusantara Buana Air, Premiair and transwista Prima Aviation; See https://en.wikipedia.org/wiki/List_of_airlines_of_Indonesia

${ }^{6}$. Banda Aceh, Medan, Pekanbaru, Jambi, Padang, Pangkal Pinang, Palembang, Batam, Bandar Lampung, Tanjung Pandan, Tanjung Pinang, Bengkulu; Kalimantan Island such as Pontianak, Balikpapan, Palangkaraya, Banjarmasin, Tarakan, Berau; Bali Denpasar; Lombok Island such Lombok, Timor Island, Kupang; Sulawesi Island such as Manado, Gorontalo, Palu, Makasar and Kendari; Jawa Island such as Jakarta, Bandung, Semarang, Solo, Yogyakarta, Malang, Surabaya; Maluku Island such as Ternate, Ambon; Papua Island such Biak, Jayapura, Timika, Sorong,Manokwari; see https://www.garuda-indonesia.com/id/en/destination/route-map/index.page

${ }^{7}$.The passes are sold in conjunction with air travel on Garuda from Europe, USA, Australia and Japan and have to be purchased from Garuda Offices in these areas. On its international network, Garuda Indonesia serves London, Amsterdam, Brussles, Frankfurt, Paris, Zurich, Rome, Vienna, Cairo, Abudhabi, Jeddah and Riyadh. In Asia and to points South, destinations are Ho Chi Min city, Bangkok, Hong Kong, Taipei, Manila, Tokyo, Kuala Lumpur, Nagoya, Seoul, Singapore, Brunei, New Zealand, Sydney, Melbourne, Perth, Darwin, Portheland and Auckland. Garuda serves Honolulu and Los Angeles as well ${ }^{8}$. http://www.indonesia-tourism.com/transport.html 
Domestic Product (GDP) almost 10\% of the global economy in 2015 and provided over 108 million jobs globally. By 2014, the World Travel \& Tourism Council (WTTC) expects direct employment in the tourism industry to be more than 126 million people globally. When looking at the jobs and GDP supported through the indirect and induced impacts of tourism, the figures are significantly higher at 285 million jobs. By 2016, tourism could support some 370 million jobs and US\$ 11 trillion in GDP. ${ }^{9}$

In Indonesia, air transportation also has a significant role to contribute the Indonesian economy. It creates jobs and generate wealth. Airlines, airport operators, airport on-site enterprises such as restaurants and retail, aircraft manufacturers, and air navigation services providers employed 190.000 people in Indonesia in 2014. In addition, by buying goods and services from local suppliers the sector supported another 530,000 jobs. On top of this, the sector is estimated to have supported a further 140,000 jobs by paying wages to its employees, some or all which are subsequently spent on consumer goods and services. Foreign tourists arriving by air to Indonesia who spend their money in the local economy, are estimated to have supported an additional 1.7 million jobs in $2014 .^{10}$

The air transport industry is estimated to have supported a US\$ .4 billion gross value added contribution to GDP in Indonesia in 2014. Spending by foreign tourists supported a further US\$ 14 billion gross value added contribution to the country's GDP. This means that 2.7 per cent of the country's GDP is supported by the air transport sector and foreign tourists arriving by air in Indonesia. ${ }^{11}$ This article purported to analysis air and transport and tourism in Indonesia.

\section{Legal Ground of Air Transportation \\ a. Air Transport Policy}

\section{Indonesian Air Transportation}

In the old order regime under President Soekarno's administration the ideology of Indonesia tended to socialist, for that reason transportation was completely run by state-owned enterprises, Garuda Indonesian Airways (GIA) ${ }^{12}$ and Merpati Nusantara Airlines (MNA), ${ }^{13}$ while the Ministry of Air Communications (MOAC) took the role of regulator. All routes, frequencies, type of aircraft, capacities and tariffs, utilization of jet or propeller aircraft were controlled and overseen by the MOAC. Within the Old Order, there were no private airlines and there was no competition between airlines because the Government set all tariffs. ${ }^{14}$

In the New Order regime under President Soeharto's administration, started to introduce a mixed ideology between socialist and liberal ideology (neo-liberal). Based on Minister Decree SK 13/S/1971, ${ }^{15}$ air transport was conducted by state-owned enterprises such as GIA ${ }^{16}$ and $\left.M N A\right)^{17}$ together with private owned enterprise such as Zamrud Aviation, Bouraq Airlines, Mandala Airlines, Seulawah Air Services, Indonesian Air Transportation, Sempati Airlines. In the neo-liberal policy GIA allowed to serve trunk line routes based on Ministerial Decree T. 14/4/4-U, ${ }^{18}$ whilst MNA,${ }^{19}$ served feeder lines together with privately owned companies such as Zamrud Aviation, Bouraq Airlines, Mandala Airlines, Seulawah Air Services, Indonesian Air Transportation, Sempati Airlines. ${ }^{20}$

In the Reformation Era, under the regime of Susilo Bambang Yudoyono (SBY), air transportation policy was relaxation (known deregulation) for the purpose to enhance tourism. Private airlines, scheduled, non-

\footnotetext{
${ }^{9}$.http://aviationbenefits.org/social-development/tourism/

10.IATA ,Economics., The Air Transport Sector Makes a Major Contribution to the Indonesian Economy .

${ }^{11}$.Ibid.

${ }^{12}$.Garuda Indonesian Airways, previously a state enterprise (PN) changed to a Limited Company (PT) based on Government Regulation Number 67 of 1971 Concerning Change from State Enterprise (PN) Perhubungan Udara to Limited Company (PT) Garuda Indonesian Airways.

${ }^{13}$.Merpati Nusantara Airlines previously incorporated as a state enterprise (PN), was changed to Limited Liability Company (PT) in Government Regulation Number 70 year 1971 Concerning Change from State Enterprise (PN) Perhubungan Udara Daerah dan Penerbangan Serba Guna "Merpati Nusantara" to Limited Liability Company (PT) Merpati Nusantara Airlines.

${ }^{14}$.Martono and Amad Sudiro.,A Book Chapters: Aviation Laws and Regulations Applicable in Indonesia. Jakarta : Rajagrafindo, 2017 Chapter Five, page... harap dicari.

${ }^{15}$.Ministerial Decree Concerning Requirements and Provisions Regarding Commercial Use of Airplanes, Ministerial Decree No.SK 13/S/1971 (18 January 1971).

${ }^{16}$. Garuda Indonesian Airways, previously a state enterprise (PN) changed to a Limited Company (PT) based on Government Regulation Number 67 of 1971 Concerning Change from State Enterprise (PN) Perhubungan Udara to Limited Company (PT) Garuda Indonesian Airways.

${ }^{17}$.Merpati Nusantara Airlines supra note 10

${ }^{18}$ Ministerial Decree Concerning Garuda Indonesian Airways Permit from Jakarta to Medan, Padang, Palembang, Belitung, Teluk Betung, Kotaradja dan Bengkulu, Ministerial Decree No. T 4/4/4-U.

${ }^{19}$.Ministerial Decree Concerning Routes Structure of PN Merpati Nusantara Airlines, Ministerial Decree No. S 8/2/5-Mphb (13 January 1969).

${ }^{20}$.Ministerial Decree Concerning Home Bases of Airlines, Ministerial Decree No.SK 402/S/70 (30 December 1970).
} 
scheduled airlines, air cargo, and charter flights as well as general aviation increased rapidly. ${ }^{21}$ Under Ministerial Decree KM 81 Year 2004, ${ }^{22}$ the requirements to establish a new airline company become very easy. Airlines compete with one another without paying attention to the interest of consumers. ${ }^{23}$ As a result of relaxation policy the number of Indonesian accidents spike tremendously. The most notable aviation accident during those period were Garuda Indonesia flight 421 emergency landing on the Bengawan Solo river on 16 January 2002, killing 1 stewardess, Lion Air flight 538 in Solo on 30 November 2004, killing 25 passengers, the Adam Air Flight 574 crash into the Makasar Strait on 1 January 2007, killing 107 passengers and its crews. The aviation safety records in Indonesia continued to plummet in a series of flight accidents. Garuda Indonesia Flight 200 in Yogyakarta on 7 March 2007 killing 21 passengers. ${ }^{24}$

In February 2007, ICAO conducted the Universal Oversight Audit Program (USOAP) resulted over 120 finding not in compliance with ICAO Standards. The Indonesian aviation authority was regarded as failing to comply with international civil flight safety by referring to USOAP-ICAO, therefore, the EU, with refers to ICAO-USOAP, considered Indonesia's civil flight operation unsafe, subsequently, all Indonesian companies' flights to Europe were banned and European citizens advised to avoid travelling to Indonesia. ${ }^{25}$

The philosophy of the Civil Act of 2009, as other states, is that airlines companies do not need a lot of airlines but they have capability to compete and are not too weak. It is better small but capable to fulfill the air transportation need to support national economic development. It is small but strong and capable to compete at national, regional and global levels. In addition, the CAA of 2009 thought based on nationality and long term period and does not thought individually in the short terms period. Based on such philosophy, the air transport policy requests the airlines establishment shall fulfill five pillars such as enough aircraft ownership, capital intensive, single majority shares, bank guarantee, professional human resources qualities as well quantities supported by aviation operation principles such as safety, security, fully regulated industry, compliances, law enforcement, high technology, and just culture.

\section{b. Civil Aviation Act of 2009}

The Indonesian civil aviation act of $2009,{ }^{26}$ which came into force on 1 st January 2009 , has been very important for the development of Indonesian air transportation. It consist of 24 (twenty four) Chapters and 466 (four hundred and sixty six ) articles. The CAA of 2009 provides among other things extra-territorial application, general provisions, foundation/bases and aims and objectives, scope of application, sovereignty over airspace, supervisions, aircraft design and production includes aircraft conceptual design, aircraft production, registration and nationality of aircraft, aircraft airworthiness and operation includes aircraft airworthiness, aircraft operation, aircraft maintenance, safety and security in aircraft during flight, aircraft personnel, insurance on aircraft operation, aircraft operation, state aircraft, international interest in aircraft object, air carrier liability includes mandatory transport, carried liability towards passengers and/or cargo shippers, transportation documents for passengers, baggage and cargo, amount of indemnity, parties entitled to receive compensation, due date of claim application, statement of possible death of passengers of lost aircraft, mandatory insurance, liability of air transportation by several consecutive carriers, liability of other carriers and third party, special requirements, structure of national airports, determination of airport, airport construction, airport operation such as airport operation certificate, airport facilities, airport personnel, activities management in airport such as government activities in airport, airport authority, business activities, special services and facilities, liability for indemnity, airport services tariff, specific airport, heliport, international airports, environmental preservation, flight navigation includes structure of national flight navigation such as air space served, flight routes, flight navigation service etc.

\section{Air Transportation Regulations}

As above-mentioned, under the CAA of 200, matters related to air services have been more clearly regulated, both from the point of view of classification of type(s) and the grouping of air services. The CAA of 2009 differentiates between scheduled air service and non-scheduled air services, and then further groups them into domestic and foreign scheduled air service and domestic and foreign non-scheduled air services. ${ }^{27}$ Each

\footnotetext{
${ }^{21}$. Indonesia Aviation: Outlook 2010, published by Indonesian National Air Carrier Association. Jakarta: 2010.

${ }^{22}$.Ministerial Decree Concerning Engagement in Air Transport. Ministerial Decree No.KM 81(2004).

${ }^{23}$.There are a lot of complaints regarding delays, cancellation, aircraft accidents, and finally consumers are victimized as a result of fierce competition.

${ }^{24}$ Runway Aviation News : Deregulasi Penerbangan Indonesia Dan Akibatnya https://web.archive.org/web/20151222111416/http://www.runway-aviation.com/deregulasi-penerbangan-indonesia-dan-akibatnya/ 31 January 2015 
category of air service has its own separate regulations under the CAA of 2009, and depending on the air service provided, there are different requirements regarding which entities may operate such services, the permits required and the tariffs that can be charged. ${ }^{28}$

\section{a. Domestic Scheduled Air Services}

The meaning of the term air services can be found in Article 96(a) of the Chicago Convention of $1944,{ }^{29}$ which provides that air service is "any scheduled air service performed by aircraft for the public transport of passengers, mail or cargo. Domestic scheduled air transportation is an air transportation activity providing air transportation from one airport to another airport within Indonesian territory. Article 1(14) of the CAA of 2009 stipulates that air transportation is any activity which uses an aircraft for transporting passengers, cargo and/or post on one or more routes from one airport to another airport or several airport. ${ }^{30}$ In relation to the level of service, air transportation can provide fully services, medium services and no-frill services.

\section{b. Class of Services}

A scheduled air transportation company is obliged to inform the consumers regarding condition and specifications of services being provided. ${ }^{31}$ Fully services means that during the flight, passengers are given food and beverages, snacks, and the use of an executive lounge for business class and first passengers. A medium level or services includes provision of light food (snack) during flight and other facilities such as executive lounges for passengers holding certain classes of tickets, whilst no-frill services have only one class of service, without any provision of food or beverages, snacks or an executive lounge. With a no-frill service, baggage can generally only be check for a fee. ${ }^{32}$

Scheduled airline providing medium and no-frill services are business entities operating on a low cost carrier basis, however they are still obliged to meet aviation safety and security requirements. They have to submit a request for authorization to the MOT and the MOT will create a scheduled air transportation business entity after all stipulated requirements are fulfilled. The scheduled air transportation company will need to be periodically evaluated, and must adhere to strict requirements licensing. ${ }^{33}$

\section{c. Business Permit}

In accordance with the requirements to operate an airline, an air transportation company shall obtain a business permit. ${ }^{34}$ To recap, a business permit will only be issued by the MOT after fulfilling administrative, share- holder, capital, aircraft ownership, business plan and human resources requirements. Administrative requirements, among others, includes the submission of a founding act, (establishment deed) of an Indonesian business entity whose business is in the field of scheduled or non-scheduled air transportation. This founding act is granted by the Minister in charged, and contain a tax identification number and a domicile letter issued by the authorized agency. If the airline company utilizes capital investment facilities, an approval letter issued by the authorized agency responsible for the capital investment, evidence of capital already deposited, a bank guarantee and a business plan for minimum of five years are all required. ${ }^{35}$

Shareholder requirements for obtaining a business permit are provided in Article 108(3) of the CAA of 2009. The CAA of 2009 provides that where the capital of a national airline owned an Indonesian legal entity or all Indonesian citizen is divided, one of the national shareholder must maintain a larger holding than any foreign shareholder. Meanwhile, capital requirements for obtaining a business permit can be found in Article 109(1)(c) of the CAA of 2009. This Article 109(1)(c) of the CAA of 2009 provides that an air transportation business entity must submit evidence of capital already deposited. Air transportation business permit will be valid as long as the permit holder continue actual air transportation activities by consistently operating aircraft in accordance with the permit granted, which will be evaluated annually. The result of the evaluation will be used as consideration for allowing the holder to continue its business activities. ${ }^{36}$

Aircraft ownership requirements for obtaining business permits are provided in Article 118 (c) of the CAA of 2009. This provision states that scheduled air transportation company must own at least five units of

\footnotetext{
28. Amad Sudiro and Martono K., National and International Air Transport Regulations in Indonesia. Vol.9(3) IOSR-JAC 8 (Mar.2016).

${ }^{29}$.Convention on International Civil Aviation, signed on 7 December 1944 at Chicago; For the text see Michael Milde Ed., Annals of Air and Space Law Vol.XVIII-1993 Part II. Toronto : The Carswell Company Ltd, at 5-77; See also Paul Dempsey Ed., Annals of Air and Space, Vol.XXX-2005 Part I. Toronto : The Carswell Company Ltd 2005, at 19-51

${ }^{30}$. Act Concerning Civil Aviation, supra note 23

${ }^{31}$. Article $97(5)$

32.Amad Sudiro and Martono K., supra note 25

${ }^{33}$.Ibid..

${ }^{34}$.Article 84 .

35. Amad Sudiro and Martono K., supra note 23.

${ }^{36}$.Article 112
} 
aircraft and possesses at five units aircraft of the type(s) suitable for supporting its business sustainability in accordance with the routes served. Air transportation companies, especially those providing cargo services, must own at least one unit of aircraft and possess at least two units aircraft of the type(s) suitable for supporting its business sustainability in accordance with the routes and operational areas to be served.

.Human resource requirements for obtaining a business permit can be found in Article 110(e) and 111 of the CAA of 009. Article 110 (e) provides that the business plan must contain human resources information regarding management personnel, technical/engineers and aircrew, whilst Article 111 of the CAA of 2009 specifically provides management requirements. This Article states that any individual may be appointed as a director of an airlines after fulfilling the following requirements such as possessing operational and managerial competence as well as experience in air transportation business management and certification of fitness after a proper test conducted by the MOT. These requirements are not applicable to the managing director of any air transportation business entity. ${ }^{37}$

A commercial air transportation business permit cannot be transferred to another party before the operational of aircraft as described in the business permit commences. Transfer of commercial air transportation business permit may only be concluded after the permit holder begins the business operation and obtain the approval of the MOT for transfer. ${ }^{38}$ Any holders of air transportation business permits violating this provision will receive administrative sanctions, namely the revocation of their business permit. ${ }^{39}$ Further provision regarding the requirements, system and procedures of obtaining air transportation business permit and appointment of airline directors are stipulated under a ministerial regulations. For this reasons, based on Article 464 of the CAA of $2009^{40}$ and 464 of the CAA of $2009,{ }^{41}$ of the CAA of 2009, Ministerial Decree No.KM 25 of $2008^{42}$

\section{d. Tariff Regulations of Air Transport}

In 1930, KLM signed an agreement with the Netherlands Indies authorities to carry approximately 500 $\mathrm{kg}$ of post, with regard to air transport's tariff for the transportation of post was negotiated between the Netherlands Indies authorities and KLM. After Indonesian independence air transport tariff regulated by the Ministry of Air Communications (MOAC), no competition between airlines. Under the new order regime of General Soeharto, Garuda Indonesia set price leadership in order to prevent unhealthy competition between airlines. There was no competition between airline due to the tariff set and regulated by MOC. All tariffs provided by private-owned companies had to be below Garuda's tariff, whilst Garuda first-class tariff was permitted to be $15 \%$ higher than normal prices for flights served using Airbus aircraft. ${ }^{43}$ In the reformation (Reformasi) Era under General Soesilo Bambang Yudoyono, airlines could compete freely with little regard for the interest of consumer. As a consequence of a more liberal air transport policy that encouraged heavy competition, airlines tended to charge a tariff less than that recommended by the MOC. ${ }^{44}$

\section{e. Tariff Policy of Air Transport}

The main function of tariff ${ }^{45}$ regulations is to secure the economic for the benefit of the travelling public and to eliminate the hazards of free competition. ${ }^{46}$ In addition, a tariff can have a significant influence on airline, travelers and regular. For airlines, a tariff that is too low may jeopardize the sustainability of an airlines' operation, whilst a tariff is too expensive may make it unaffordable for travelers to travel. For the regulator, a tariff is a means to regulate the balance of the sustainability of airlines' operations and to guarantee that travelers can afford the price for the benefit of the travelling public. For these reasons, tariff must be carefully regulated by the regulator. ${ }^{47}$

As discuss above-mentioned in bilateral and as standardized by ICAO, air transport tariff in this Article refer to tariff, rates and fares or payment related to air transportation. Tariff could therefore concern

\footnotetext{
${ }^{37}$. Amad Sudiro and Martono K., supra note 23.

${ }^{38}$.Article 113 .

39. Article 113

40. Article 464 of the CAA of 2009 provides that at the time of this law becoming effective, all implementing regulations under Act No.15 Year 1992, on Civil Aviation shall remain valid as long as it is not contrary or changed by a new provision under this law.

41. Article 464 of the CAA of 2009 provides that at the time this law becomes effective, the Act No.15 Year 1992 on Civil Aviation (State Gazette of the Republic of Indonesia No.53, Supplement State Gazette of the Republic of Indonesia No.3481.

${ }^{42}$. Ministerial Decree Concerning Engagement of Air Transportation, Ministerial Decree, KM 25 (25 November 2008.

${ }^{43}$.Ministerial Decree Concerning Domestic Tariff Changes, Ministerial Decree No.KM96/PR.303/Phb-84 ( 1 May 1984); See Amad Sudiro and Martono. supra note 23.

44. Amad Sudiro and Martono.,supra note 23.

45. International Civil Aviation Organization's Standard Bilateral Tariff Clauses, ICAO Doc.9228-C/1036 (1978) [Standard Bilateral Tariff Clauses]

46. LCJ Lehtonen, The Bilateral Air Transport Agreement of Finland : A Study in Public International Air Law, (LLM Thesis, McGill University Institute of Air and Space Law, 1977 at 178 (unpublished).

47. Amad Sudiro and Martono., supra note 23. 
matters as ticketing of national passengers service fees without air navigation fees, landing fees, stand parking fees, aircraft storage service fees and so on. Domestic tariffs are discussed in Part four of the CAA of 2009 and consist of tariff for scheduled air transportation of passengers and shipment of cargo. Basically, tariff policies are neo-liberal in nature since the tariffs consist of economy and non-economy class tariffs are determined by airline companies based on market forces. ${ }^{48}$

\section{f. Passenger Tariffs for Scheduled Air Transport}

The tariff set by the MOC have an upper limit which takes into account factors such as the need to protect consumers and prevent unfair competition. On the whole, Indonesia's air transport regulations protect consumers by indirectly specifying a lower limit for the determination of tariffs, and at the same time the tariff regulations also prevent under pricing practices by air service providers that aim to squeeze competing carriers out of the market. At first glance, however, it appears that this determination of tariffs does not adequately factor in the commercial side of the air service industry, especially for those offering premium services. ${ }^{49}$

In determining tariffs, the MOC considers the interest of aviation safety and security, as well as the needs of the public and airlines' operation. ${ }^{50}$ MOC Decree Number 26 of $2010,{ }^{51}$ clarifies how passenger tariffs for economy class are determined and that they are based on the distance flown, tax, mandatory accident insurance and surcharges. The distance tariff is the amount of tariff per flight route per trip, for each passenger, and is a calculation based on the basic tariff multiplied by the distance. This formula also factors in the nation's purchasing power or affordability of the tariff. The distance tariff consist of a basic average fee plus a reasonable profit a value-added tax based on taxation regulations. ${ }^{52}$ Mandatory passenger accident insurance is required by laws and regulations. Surcharges are imposed based on additional costs that the air transportation company has to pay to operate the business. The provision stipulates that the distance tariff may be adjusted due to factors such as, among others, the fluctuation of fuel prices. Costs that the air transportation company must bear due to lack of passengers on returning flights, outbound or inbound, are also included in the calculation of the tariff. With regard to the fluctuation of fuel prices, the MOC recently issued the increase the amount of surcharges consistent with the value of American dollars. ${ }^{53}$

Tariffs ceiling for domestic economy class passengers are stipulated by the MOC to prevent the imposition of high tariffs by airline companies and protect consumers from misleading advertising. The tariff for scheduled economy class passengers is disseminated either by the MOC or by the airlines themselves through print and electronic media and/or presented to consumers wherever airplane tickets are sold. Domestic airlines are prohibited from selling economy tickets above the tariff ceiling provided by the MOC, and any airline violating this prohibition will receive sanctions in the form of a warning and/or flight route permit revocation. ${ }^{54}$

In addition, domestic passenger tariffs for economy class consist of tariffs based on whether the aircraft used is a jet-powered or propeller powered aircraft. ${ }^{55}$ Indonesia's DGAC proposes the maximum tariff after coordinating with national air carrier associations and consumer associations, and the tariff is also reflective of the class of service provided. Airlines providing fully service may charge $100 \%$ of the maximum tariff, whereas airline providing medium service my charge $90 \%$ of the maximum tariff, and airlines providing no-frills service may charge only $85 \%$ of the maximum tariff.

\section{g. Best Tariff Practices}

\section{1). Scheduled Airlines Operations}

As mentioned earlier, tariff policies in Indonesia are basically neo-liberal in nature, as the tariffs consist of economy and non-economy tariffs. Economy class tariffs are regulated by the MOC in order to ensure the viability of public transportation and to protect the interest of the traveler. An upper limit is set by the MOC to prevent unfair competition between airlines and airlines are prohibited from selling economy tickets above the upper limit tariff established by the MOC. In practice, however, the competition between scheduled airlines can be very fierce, and, as a result of the operation of the market, air services have been classified into three categories of tickets in order to avoid the restrictions set by the MOC. There are daily, weekly and monthly fares.

\footnotetext{
${ }^{48}$.Ibid.

49. Martono and Amad Sudiro.,Current Air Transport Regulation in Indonesia (201) XXXVIII Ann. Air \& Sp.L.at 55; See also Amad Sudiro and Martono.supra note 23.

${ }^{50}$. Civil Aviaton Act, supra note 9, art 126.

${ }^{51}$. Ministerial Decree Concerning the Calculation Mechanism and Determination of Ceiling Passengers for Economy TariffClass of Air Transportation Domestic Services, Ministerial Decree No.26 (14 April 2010)[Decree Concerning the Calculation].

${ }_{53}^{52}$.Martono \& Sudiro,"Current", supra note 46 at 81.

53. Ministerial Regulation Concerning the Amount of Surcharges of Domestic Scheduled Transportation Tariffs, Ministerial Regulation No.PM 2 of 2014 (16 February 2014).

${ }_{55}^{54}$.Martono \& Sudiro,"Current", supra note 46, at 82.

55. Ministerial Decree Concerning the Calculation, supra note 48

DOI: 10.9790/5736-1005010119

www.iosrjournals.org

6 |Page
} 
Daily tickets consist of prime-time tickets for flights between 4.30 a.m. and 9.30 a.m., which are very pricey, and tickets for flights between 12.00 p.m. and 3.00 p.m., which are the cheapest. In the weekly category, flights on Tuesdays, Wednesdays and Thursdays are very cheap, and flights on Fridays, Saturdays and Sundays are very expensive. However, even if the price is very expensive, no price is higher than the upper limit tariff. In addition, there are other variations such as promotional tariffs and normal economy tariffs. Promotional tariffs are cheaper than normal economy class, while economy tariffs consist of regular economy class flexible economy class and rigid economy class fares. This strategy not only avoids the price restrictions set by the MOC, but also, in effect influences the behavior of consumers and the travelling public

\section{2). Holiday Season of Scheduled and Non-Scheduled Operations}

Especially in the holiday months, such as school holidays, celebration of days significant to Muslims (such as Lebaran) and the Christmas holidays, tickets price almost reach the upper limit established by the MOC. During those periods, the demand for travel increases significantly and almost all domestic scheduled airlines provide extra flights to cater to these demands. For non-scheduled airlines, and, in response to the increase in demand during peak travel periods, tariffs are subject to negotiation between the user and the provider of air transportation.

\section{3). Control of the Applicable Tariff}

During school holidays, Muslim holidays and Christmas holidays, the MOC rigidly controls the implementation of tariff regulations. Scheduled airlines are obliged to disseminate the tariff through print and electronic media and/or by presenting the set price on every airplane ticket. Any airline violating these provisions will receive administrative sanctions in the form of a warning and/or risk the flight permit being revoked. $^{56}$ In the three years since the Civil Aviation Act of 2009 came into effect, no scheduled airline has violated the upper limit on tariffs as set by the MOC, meaning that all scheduled airline are complying voluntarily with such regulations.

\section{h. Conclusion and Recommendation}

As the national level, the regulation of tariffs in Indonesia is consists with the overriding national ideology of neo-liberalism, which aims to protect the travelling public and to guarantee the sustainability of airlines' operation in a competitive environment. In addition, the travelling public has the right and opportunity to choose from a range of prices which have come into being as a result of the tariff ceiling set by Indonesia's Ministry of Communications, and also as a result of competitive practices between air service providers. As practice demonstrates, Indonesian airlines have to date accepted all tariff regulation set up by the government.

Though there are various regulations, both international and national, in place to control tariffs, Indonesia still needs to contend with a number of weakness and inherent problems. These were highlighted by the Indonesian infrastructure. Initiative report produced in 2010, in which the major concerns related to the lack of compliance with international aviation safety and security standards, poor aviation and air navigation infrastructure and services, as well as inadequate training and management of human resources. The government must pay significantly more attention to these deficiencies in order to foster the continued growth and future development of the aviation industry in Indonesia.

\section{International airports}

Each of the larger Indonesian islands have at least one international airport. The biggest airport in Indonesia, Soekarno-Hatta International Airport, is located in Tangerang Regency, Banten. There are five more international airports on Java, such as Adisumarmo International Airport in Solo, Central Java, Juanda International Airport in Surabaya, East Java, Achmad Yani International Airport in Semarang, Central Java, Husein Sastranegara International Airport in Bandung, West Java and Adisucipto International Airport in Yogyakarta. On Kalimantan, there is one international airport and there are two on Sumatra such as Minangkabau International Airport in Padang, West Sumatra. Bali, which is part of the Nusa Tenggara Islands, has the Ngurah Rai International Airport, Selaparang Airport located on the west coast of Lombok was closed to flight operations on 30 September 2011. The new Lombok International Airport opened on 1 October $2011 .^{57}$

Selaparang Airport will either be redeveloped or may possibly be retained for development as Indonesia's first General Aviation hub airport. Sam Ratulangi International Airport, also known as Manado International Airport, is located in North Sulawesi, 13 kilometres northeast of Manado. The airport is named after the Minahasan educator and independence hero Sam Ratulangi. The Manado airport is also a hub to remote

\footnotetext{
${ }^{56}$. Martono \& Sudiro, '"Current", supra note 46 at 82.

${ }^{57}$.Claire Harvey (5 May 2002). "'Kuta Cowboys' strutting their stuff for lovelorn visitors". The Jakarta Post. Retrieved 16 October 2014; http://www.airports.org/aci/aci/file/ADN\%20-\%20Momberger/ACI-ADN\%20Dec\%202005.pdf; New Lombok International Airport, The Directorate General of Air Communication, and PT. (Persero) Angkasa Pura 1, Project Summary, Jakarta, 4 January 2005.

DOI: $10.9790 / 5736-1005010119 \quad$ www.iosrjournals.org 7 |Page
}


areas of Eastern Indonesia, including Halmahera with both Kao airport as well as Galela, Ambon, Tidore, and Irian Jaya or West Papua. There are also direct flights to Manado International Airport from Singapore daily with Silk Air a wholly owned subsidiary of Singapore Airlines. There are three major tourists international airports arrivals, i.e. Ngurah Rai International Airport with 2.54 million, Soekarno-Hatta Airport with 1.82 million and Hang Nadim Airport, also known as Hang Nadim International Airport, in Batam, Riau Islands with 1.007 million from 7.002 million international tourists recorded as arriving in Indonesia during $2010 .^{58}$

\section{Air Transportation and the Tourist's Destination}

\section{Indonesian Air Transport And Tourism}

As above-mentioned describes that air transport is the easiest and most comfortable means of travel in Indonesia. There are available to all provincial district capitals and other remote areas operated by Garuda Indonesia, the national flag air carrier, both domestic and international routes. Domestically serves 33 cities including all the provincial capitals. Garuda Indonesia has several daily flights from Jakarta to destination of commercial and touristic importance, such as Bali, Medan, Ujung Pandang, Manado and Yogyakarta. It also operates shuttle flights to Surabaya and Semarang several times a day. For visitors Garuda Indonesia has introduced Visit Indonesia Air Passes which offers special fares on its domestic flights. The passes are sold in conjunction with travel on Garuda from Europe, USA, Australia and Japan, and have to be purchased from Garuda Offices in these areas. On its international network, Garuda Indonesia serves London, Amsterdam, Brussles, Frankfurt, Paris, Zurich, Rome, Vienna, Cairo, Abudhabi, Jeddah and Riyadh. In Asia and to points South, destinations are Ho Chi Min city, Bangkok, Hong Kong, Taipei, Manila, Tokyo, Kuala Lumpur, Nagoya, Seoul, Singapore, Brunei, New Zealand, Sydney, Melbourne, Perth, Darwin, Portheland and Auckland. Garuda serves Honolulu and Los Angeles as well. ${ }^{59}$

Formerly, Merpati Nusantara Airlines (MNA) is the second national carrier and flies to about 110 destination in Indonesia and has some border crossing flights to Australia (Darwin), Brunei Darussalam, Davao (Philippines), and East Malaysia (Kuching), whilst previously Bouraq and Mandala also have scheduled services. There are some other privately owned airlines which mainly operate charter flights. Indonesia's three main gateways are Soekarno-Hatta International Airport, Jakarta, Polonia Airport in Medan and Ngurah Rai Airport in Bali. Several international airlines serve Jakarta. Medan receives direct flights from Singapore, Penang and Kuala Lumpur operated by Singapore Airlines, Malaysian Airlines System (MASj, Silk Air and Garuda. ${ }^{60}$

Bali is served by Garuda and Qantas and since 1986 Garuda initiated joint services with SIA, MAS, Cathay Pacific, JAL, Silk Air, China Airlines, Thai Airways Int'l, Continental Airlines and Royal Brunei for direct flights to Bali from Singapore, Kuala Lumpur, Bangkok, Brunei Darussalam, Guatemala, Hong Kong, Nagoya, Osaka, Tokyo, and Taipei and other service from Amsterdam, through Vienna and Abudhabi to Medan and Bali, offering easier accessibility and overflying Jakarta. ${ }^{61}$

\section{Tourist's Destination in Indonesia}

Large and small Islands in Indonesia offers a variety of natural, art and culture charms that will not be easy forgotten. An archipelago is divided into thousands of islands must offer exceptional beauty, such as beaches, underwater scenery, mountains to the jungle filled with various flora and fauna. Not only that, the people who live across archipelago this country also have different customs and cultures and even their languages are different from one another. It will be an incredible experience. Indonesia was gifted beautiful beaches, from soft white sand, clear and calm water to the challenging waves for surfers and also offers the natural beauty of the amazing underwater up that it is a paradise for divers such as Weh Island in Nanggroe Aceh Darussalam, Karimunjava in Central Java, Wakatobi in Southeast Sulawesi, Bunaken in North Sulawesi, to the beauty of the underwater world Raja Ampat in West Papua that is so fascinating. In addition, there are the charm of the land such as Karo traditional house in the village of Linga, North Sumatra, the famous Jam Gadang (big clock) in Bukittinggi, West Sumatra, the elephants in Way Kambas National Park Lampung and Raflessia Arnoldii, the largest flower in the world, is grown on the island of Sumatra, Bengkulu province, the presence of endangered orangutans in Kalimantan, the enchantment of Blue fire in the crater of Mount Ijen, Banyuwangi, East Java etc. ${ }^{62}$

\footnotetext{
${ }^{58}$."Surpassing 2010 target, RI aims to lure $7.7 \mathrm{mln}$ tourists". Retrieved 11 June 2015); Tourism in Indonesia https://en.wikipedia.org/wiki/Tourism in Indonesia From Wikipedia, the free encyclopedia.

${ }^{59}$.AIR TRANSPORTATION http://www.indonesia-tourism.com/transport.html.

${ }^{60}$. Ibid.

${ }^{61}$.lbid.

62. Welcome INDONESIA, WONDEFUL INDONESIA.

DOI: $10.9790 / 5736-1005010119 \quad$ www.iosrjournals.org 8 |Page
}




\section{a. Sumatra Island}

Sumatra Island consist of eight provinces such as Nanggroe Aceh Darussalam, North Sumatra, West Sumatra, Riau, Jambi, South Sumatra, Bengkulu and Lampung. With regard to tourist destination, from North to the South such as Saman Dance Performance. The traditional dance which demonstrates full concentration and accuracy of highly energetic movements and distinctly marked by incredibly rapid hand movements and uniformity; Berastagi in the North Sumatra's province, the cool and fertile city flanked by two volcanic mountains, Mount Sibayak and Mount Sinabung, preserves many stories of the early $20^{\text {th }}$ century East Indie Dutch colonial time; Nias Island for one who interested in surfing and to learn about the tropical rainforest ecosystem, there are several national parks can be visited in this Island.

Toba Lake is one of the most popular tourist destinations in Indonesia, especially in North Sumatra. Toba Lake is the largest volcanic lake in Indonesia, even in the Southeast Asia, which make it more special is taken from the Samosir Island, an Island that settled in the middle of the lake. Lake Toba is an area of 1,707 $\mathrm{km}^{2}$, this is $1,000 \mathrm{~km}^{2}$ bigger than Singapore. It formed by a gigantic volcanic eruption some 70,000 years ago, it is probably the largest resurgent caldera on Earth. Samosir Island in the middle, was joined to the caldera wall by a narrow isthmus, which was cut through to enable boats to pass; a road bridge crosses the cutting. Samosir island is the cultural center of the Batak tribe, the indigenous from North Sumatra. By the eruption of a super volcano (Mount Toba) was estimated to have caused mass death and extinction of several species of living creatures. The eruption of Mount Toba has led to changes in the earth's weather and the start into the ice age that affects the world civilization. Lake Toba is actually more like a sea than a lake considering its size. Therefore, the Lake placed as the largest lake in Southeast Asia and the second largest in the world after Lake Victoria in Africa. Lake Toba is also includes the deepest lake in the world, which is approximately 450 meters. ${ }^{63}$ Mentawai Island off the western coast of Sumatra to explore the well-preserved indigenous people's traditional customs; Bangka Belitung province south Sumatra offers attractive diving and snorkeling spots etc.

\section{b. Java Island}

Java Island consist of six provinces such as Special Capital City Region of Jakarta (DKI), Banten, West Java, Central Java, East Java and Special Regional of Yogyakarta. From the west to the east of tourist destination such as Ujung Kulon National Park and Mount Anak Krakatau has been declared by UNESCO as World Heritage sites; There are more than 50 museums housing variety of crafts and historical artefacts from throughout the country. Jakarta during the Dutch colonial era used to be referred to as Batavia. One of the icons of the metropolitan city is the National Monument or more popularly known as Tugu Monas. The 132 meter high monument is decked with a gold leaf covered flame on top; Tangkuban Perahu in Lembang West Java, Borobudur Temple is the world's largest Budhist temple that built by King Samaratungga in 824 AD in Yogyakarta, a unique ride on an old train passing along pretty landscapes of mountains, plantations and local villages. The old train of 1902 made-in-German steam locomotive train chuffs along leisured by the local teakwood. This train is showcased at the train Mueseum in Ambarawa, Central Java; The Bromo Tengger Semeru National Park is located in East Java. Between December and January there is the traditional ritual of Kasodo held on full moon by the indigenous people of the Tengger tribe to ask for abundant harvest or to ward off evil spirit and for recovery from various illnesses, by throwing offerings to the crater of Mount Bromo. ${ }^{64}$

\section{c. Kalimantan Island}

Kalimantan Island consist of 5 (five) provinces such as North Kalimantan, East Kalimantan, West Kalimantan, Central Kalimantan and South Kalimantan. With regards to this Island is a paradise for flora and fauna lovers that offers a vast range of potentials for adventurous travelers are keen on eco-travel activities. Erau traditional ritual serves as an excellent example. Held annually by the Sultanate of Kutai Kartanegara in East Kalimantan, it is marked by Mengulur Naga and Belimbur water splashing rituals by the local people throughout the city as a conclusion to the whole series of ceremony. ${ }^{65}$

\section{d. How to get to Komodo Island}

Exploring the Komodo National Park is very easy, but one should need to Bali first to get a plane or a boat. There are 4 ways to discover the Komodo's park such as fly from Bali airport to Labuan Bajo located on Flores Island. Labuan Bajo is the best base to explore the Komodo National Park. From there one can go diving with one of the local dive center during daytrips in the marine reserve; from Labuan Bajo one can get a diving Live a board to take a tour of the Komodo islands and the best diving sites; than one can charter a boat in Labuan Bajo and make his/her own private cruise around the Komodo Islands, perfect for discovering the

\footnotetext{
${ }^{63}$. http://www.indonesia-tourism.com/north-sumatra/toba lake.html

${ }^{64}$.Welcome, supra note 59 at 39.

${ }^{65}$. Ibid. at 47. 
archipelago and for snorkeling. From Bali, one can take a Live a board which will take him/her to a splendid diving cruise around Lombok Island and the Komodo marine reserve. Flights from Bali to Labuan Bajo are operated by small companies with small planes. The flight is very scenic so be sure to get a window seat to get a glimpse of the spectacular views and small planes are often full so it is better to book his/her seat in advance. Otherwise, for the more adventurous and the ones who are travelling on a tight budget can take the public ferry from Bali to Labuan Bajo. It will take about 3 days and the journey is an adventure in itself. ${ }^{66}$

\section{Indonesian Airlines}

In Indonesia, there are two type (s) of Aircraft Operating Certificate (AOC) such as AOC 121 and AOC 135. AOC 121 is for commercial scheduled airlines with more than 30 passengers, ${ }^{67}$ whilst AOC 135 is for commercial scheduled airlines with more than 30 passengers and chartered airlines, ${ }^{68}$ there are 22 AOC 121 holders and 32 AOC 135 holders. Aviation market share in Indonesia are Lion Air 41.6\%, Garuda Indonesia 23.5\%, Sriwijaya Air 10,4\%, Citilink 8,9\%, Wing Air 4,7\% Indonesian Air Asia 4.4\% and Others 6,5\%. With regard to domestic scheduled airlines there are 27 airlines, ${ }^{69}$ and there 8 (eight) charter airlines. ${ }^{70}$

\section{Routes Structure}

\section{a. Lion Air's Destination}

Lion Air base in Soekarno-Hatta International Airport connects to over 36 destinations and operates to Java Island such as Jakarta, Semarang, Yogyakarta, Surabaya, Solo; Sumatra Island such as Banda Aceh, Medan, Pekanbaru, Palembang, Padang, Jambi, Bengkulu, Batam, Pangkal Pinang; Kalimantan such as Pontianak, Banjarmasin, Balikpapan, Tarakan; Sulawesi such as Manado, Gorontalo, Palu, Kendari, Makasar, Ternate, Ambon; Papua such as Sorong, Fak-fak, Nabire, Jayapura; Denpasar in Bali, Mataram, Sumbawa and Kupang. In addition, Lion Air also serves international flight such as Ho Chi Minh City in Viet Nam.

\section{b. Garuda Indonesia's Destinations}

In the domestic routes, Garuda Indonesia flies to Sumatra Island such as Banda Aceh, Medan, Pekanbaru, Jambi, Padang, Pangkal Pinang, Palembang, Batam, Bandar Lampung, Tanjung Pandan, Tanjung Pinang, Bengkulu; Kalimantan Island such as Pontianak, Balikpapan, Palangkaraya, Banjarmasin, Tarakan, Berau; Bali Denpasar; Lombok Island such Lombok, Timor Island, Kupang; Sulawesi Island such as Manado, Gorontalo, Palu, Makasar and Kendari; Jawa Island such as Jakarta, Bandung, Semarang, Solo, Yogyakarta, Malang, Surabaya; Maluku Island such as Ternate, Ambon; Papua Island such Biak, Jayapura, Timika, Sorong,Manokwari. ${ }^{71}$

In addition, Garuda Indonesia as flag air carrier also serves international flight such as Singapore, Kuala Lumpur, Bangkok, Penang, Hong Kong, Tokyo (Narita), Tokyo (Haneda), Osaka, Seoul, Guangzhou, Beijing, Shanghai, Taipei, Manila, Ho Chi Minh City, Bandar Seri Begawan, Middle East such as Jeddah, Abu Dhabi, Muscat (codes share Paris, Manchaster, ${ }^{2}$ Australia such as Perth, Melbourne, Sydney, Brisbane; United States of America such as Los Angeles ${ }^{7}$. San Fransisco ${ }^{7}$ Europe such as Amsterdam, London Heathrow ${ }^{1,2}$, Frankfurt, ${ }^{1}$ Zurich, ${ }^{1}$ Madrid, ${ }^{1}$ Munich,,${ }^{1}$ Rome,${ }^{1}$ Paris, ${ }^{2}$ Manchaster,${ }^{2}$ Athena, ${ }^{2}$ Moscow, 2 Istanbul. ${ }^{3}$

\section{c. Sriwijaya Air destinations}

Sriwijaya Air the third ranking of Indonesian airlines serves domestic routes to Java such as Bandung, Jakarta, Malang, Semarang, Solo, Surabaya, Yogyakarta; Sumatra such as Banda Aceh, Lampung, Batam, Bengkulu, Jambi, Medan, Padang, Palembang, Pekanbaru, Tanjung Pinang; Kalimantan such as Balikpapan, Banjarmasin, Palangka Raya, Pontianak, Tarakan; Sulawesi such as Ambon, Gorontalo, Kendari, Makassar, Manado, Palu; West Papua such as Sorong, Manokwari. In addition, Sriwijaya Air also serve international flight such as Penang (Malaysia), Davao (The Philippines) and Singapore. ${ }^{72}$

\footnotetext{
${ }^{66}$.http://divezone.net/travel/komodo-island

${ }^{67}$.https://en.wikipedia.org/wiki/List_of_airlines_of_Indonesia access on 4/9/2017

${ }^{68}$. Ibid.

${ }^{69}$.Airfast Indonesia, Airmark Indonesia, Air Regional, Aviastar (Inodnesia), Batik Air, Citilink, Dimonim Air, Garuda Indonesia, Indonesia Air Asia, Indonesia AirAsia X, Indonesia Air Transport (IAT), Jhonlin Air Transport, Kalimantan Air Services, Kalstar Aviation, Kaltim Airlines, Lion Air, NAM Air, Pelita Air Services, Sky Aviation, Sriwijaya Air, Susi Air, Transnusa Air Services, Travira Air, Trigana Air Services, Wing Air and Xpress Air.

${ }^{70}$.Air Born Indonesia, Eastindo, Gatari Air Services, Mimika Air, Nusantara Air Charter, Nusantara Buana Air, Premiair and transwista Prima Aviation; https://en.wikipedia.org/wiki/List of airlines of Indonesia.

${ }_{71}^{71}$ https://www.garuda-indonesia.com/id/en/destination/route-map/index.page

${ }^{72}$ https://en.wikipedia.org/wiki/Sriwijaya Air destinations From Wikipedia, the free encyclopedia

DOI: 10.9790/5736-1005010119 www.iosrjournals.org 


\section{d. Citilink's Destination}

Citilink is low-cost airline based on Soekarno-Hatta International Airport, as a low-costs subsidiary of Garuda Indonesia, set up to operate shuttle services between Indonesian cities. Its main hub is Juanda International Airport in Surabaya serves Jakarta, Bandung, Yogyakarta, Solo, Surabaya, Denpasar in Bali, Balikpapan, Banjarmasin, Ambon, Medan, Pekanbaru, Padang, Batam, Palembang, Pangkal Pinang etc.

\section{e. Wing Air and Tourism}

Wing Air as a Lion Air's regional subsidiary operates a fleet of 16 ATR 72-500s across its domestic network in Indonesia. Since early 2010, Wings Air is significantly contributing to the development of regional air connectivity across Indonesia, using its ATR 72s to create new routes from main and regional airports, adding frequencies into most popular routes and feeding Lion Air's B-737-900ERs operations at its hubs in Surabaya, Yogyakarta, Denpasar, Medan, Batam, Makasar, Ambon and Menado. The fleet of ATR 72s of Wings Air is also developing and enhancing air services into some remote areas of the country. These next 44 ATR 72-500/600s to be delivered to Wings Air will continue to develop new routes departing mainly from Sumatera, Kalimantan, Sulawesi and Papua islands. Some of these aircraft will also replace and complement Wings Air's MD-80s and Lion Air's B-737s operating from these airports, thus adding new frequencies into the network. ${ }^{73}$

According to Rusdi Kirana, Chairman of Wings Air and President of Lion Air, Wing Air's fleet of ATR 72s is playing a major role in the development and democratization of the aviation services in Indonesia, bringing new travel possibilities, at low rates, to an increasing part of the population. With the ATRs, Wings Air is also contributing to develop business opportunities across the country and to develop tourism in regions like Java, Bali and Nusantagara. The ATR aircraft are perfectly adapted to the Indonesian short-haul market and allows Wings Air to connect communities, even those located in remote areas. They are also contributing to the preservation of the environment thanks to their very low $\mathrm{CO} 2$ emissions rate". ${ }^{74}$

\section{f. Indonesia Air Asia's Destinations}

PT Indonesia AirAsia is low-cost airline base in Soekarno-Hatta International Airport serves domestic commercial scheduled to Bandung, Denpasar, Jakarta, Lombok, Medan, Palembang, Pekanbaru, Semarang, Surabaya and Yogyakarta. In addition, Indonesia Air Asia also serves international flight such as Darwin ant Perth in Australia, Kuala Lumpur, Penang and Johor in Malaysia, Bangkok and Phuket in Thailand, Singapore as well. ${ }^{75}$

\section{Introduction}

\section{Indonesian Tourism Industry}

In year 2015, the total of international visitors entered Indonesia was 9.73 million, staying in hotels for an average of 7.5 nights and spending an average of US $\$ 1,142$ per person during their visit, or US $\$ 152.22$ per person per day, ${ }^{76}$ Singapore, Malaysia, China, Australia, and Japan are the top five sources of visitors to Indonesia. The Travel and Tourism Competitiveness Report 2015 ranks Indonesia 50th out of 141 countries overall. The report ranks the price competitiveness of Indonesia's tourism sector the 3rd out of 141 countries. It mentions that Indonesia has quite good travel and tourism policy and enabling conditions (ranked 9th). The country also scores quite good on natural and cultural resources. However, the country scored rather low in infrastructure sub-index (ranked 75th), as some aspect of tourist service infrastructure are underdeveloped. ${ }^{77}$

In 2016, the government was reported to be investing more in tourism development by attracting more foreign investors. The government has given priority to Java, Sumatra, Bali, Sulawesi, North Maluku, BATAS KOREKSI TGL16 APRIL 2017 West and East Nusa Tenggara, Tanjung Kelayang, and Belitung. As quoted in the Jakarta Post, the government is aiming for 275 million trips by domestic tourists by end of $2019 .^{78}$ The government has also secured commitments from potential investors, totaling US\$70 million in the areas of building accommodation, marina and ecotourism facilities in 3 of the 10 areas. ${ }^{79}$

\footnotetext{
${ }^{73}$ PRESS RELEASES., Indonesia's Wings Air to become the largest ATR operator with 60 aircraft. http://www.atraircraft.com/newsroom/press-releases-details-1175-en.html 16 February 2012 Access on 4/9/2017

74. lbid. .

75 .Indonesia Air Asia., https://en.wikipedia.org/wiki/Indonesia AirAsia From Wikipedia, the free encyclopedia.

${ }^{76}$.Indonesia Investments. "2013's Growing Number of Tourists in Indonesia Meets Government Target". Retrieved 11 June 2015.

${ }_{77}$.Travel and Tourism Competitiveness Report 2015 - Indonesia". weforum.org. Retrieved 25 September 2016; Tourism in Indonesia https://en.wikipedia.org/wiki/Tourism_in_Indonesia From Wikipedia, the free encyclopedia.

${ }^{78}$. http://www.thejakartapost.com/news/2016/09/06/government-prioritizes-tourism-development-10-regions.html .

${ }^{79}$.http://www.thejakartapost.com/news/2016/09/06/government-prioritizes-tourism-development-10-regions.html

DOI: 10.9790/5736-1005010119 www.iosrjournals.org 11 Page
} 


\section{Historical Development of Tourism}

Initially the tourism, service and hospitality sector in Dutch East Indies were developed to cater the lodging, entertainment and leisure needs of domestic visitors, especially the wealthy Dutch plantation owners and merchants during their stay in the city. In the 19th century, colonial heritage hotels equipped with dance halls, live music and fine dining restaurants were established in Dutch East Indies urban areas, such as Hotel des Indes, in Batavia (now Jakarta), Savoy Homann Hotel in Bandung, Hotel Oranje in Surabaya, and Hotel De Boer in Medan. Since the 19th century Dutch East Indies has attracted visitors from The Netherlands ${ }^{80}$ The first national tourism bureau was the Vereeeging Toeristen Verkeer, established by Governor General of Dutch East Indies in early 20th century, and shared their head office in Batavia with Koninklijke Nederlansch Indische Luchtfahrt Maatschapijj (part of KLM) that began to fly from Amsterdam to Batavia in $1929 .{ }^{81}$ In 1913, Vereeneging Touristen Verkeer wrote a guide book about tourism places in the Indies. Since then Bali become known to international tourist with foreign tourist arrivals rose for more than $100 \%$ in $1927 .{ }^{82}$ Much of the international tourism of the 1920s and 1930s was by international visitors on oceanic cruises. The 1930s did see a modest but significant influx of mainly European tourists and longer term stayers to Bali. Many came for the blossoming arts scene in the Ubud area, which was as much a two-way exchange between the Balinese and outsiders as it was an internal phenomenon. ${ }^{83}$

Tourism more or less disappeared during World War II, Indonesian National Revolution and in the early years of the Sukarno era. On 1 July 1947, the government of Republic of Indonesia tried to revive tourism sector in Indonesia by establishing Hotel National \& Tourism. This new national tourism authority took over many of the colonial heritage hotels in Java and renamed them all "Hotel Merdeka. In 1952 the President formed the Inter-Departement Committee on Tourism Affairs which is responsible for reestablishing Indonesia as the world's tourism destination. National pride and identity in the late 1950s and early 1960s was incorporated into the monumentalism of Sukarno in Jakarta - and this included the development of grand multi-storied international standard hotels and beach resorts, such as Hotel Indonesia in Jakarta, Ambarrukmo Hotel in Yogyakarta, Samudra Beach Hotel in Pelabuhan Ratu beach West Java, and Inna Grand Bali Beach Hotel in Bali. The political and economic instability of the mid-1960s saw tourism decline radically again. Bali, and in particular the small village of Kuta, was however, in the 1960s, an important stopover on the overland hippy trail between Australia and Europe, and a "secret" untouched surf spot. ${ }^{84}$

-In the early 1970s, high standard hotels and tourist facilities began to appear in Jakarta and Bali. After the completion of Borobudur restoration project in 1982, Yogyakarta become a popular tourist destination in Indonesia after Bali, mostly attracted to this 8th-century Buddhist monument, surrounding ancient Javanese temples and Yogyakarta Sultanate palace. From this period to the end of the Suharto era, governmental policies of the tourism industry included an array of regulations and developments to encourage increasing numbers of international tourists to both visit Indonesia and stay longer. ${ }^{85}$

\section{Indonesian Domestic Tourist}

According to the Central Statistics Agency (BPS), the ten most popular tourist are Bali, West Java, Central Java, East Java, Jakarta, North Sumatra, Lampung, South Sulawesi, South Sumatra, Banten and West Sumatra (which would make it 11 provinces today due to Banten previously having been a part of West Java). ${ }^{86}$ As with most countries, domestic tourists are by far the largest market segment. The biggest movement of domestic tourists is during the annual Eid ul-Fitr, locally known as lebaran. During this period, which is a two-week holiday after the month of fasting during Ramadan, many citydwelling Muslim Indonesians visit relatives in their home towns. Intercity traffic is at its peak and often an additional surcharge is applied during this time.

Over the five years up to 2006, attention has been focused on generating more domestic tourism. Competition amongst budget airlines has increased the number of domestic air travellers throughout the country. Recently, the Ministry of Labor legislated to create long weekends by combining public holidays that fall close to weekends, except in the case of important religious holidays. During these long weekends, most hotels in popular destinations are fully booked. ${ }^{87}$ Since 2000 , on average, there have been five million foreign tourists each year, who spend an average of US\$100 per day. With an average visit duration of 9-12 days, Indonesia

\footnotetext{
${ }^{80}$.Dieny Ferbianty. "Sejarah Pariwisata Indonesia" (PDF). Retrieved 27 June 2011.

${ }^{81}$.Ibid.

82 . Ibid.

83 .Robert Cribb, 'International tourism in Java, 1900-1930, South East Asian Research 3 no 2 (1995), pp. 193-204. ISSN 0967-828X.

${ }^{84}$.Elliot, Mark (November 2003). Indonesia. Lonely Planet. ISBN 1-74059-154-2

${ }^{85}$.Tourism in Indonesia https://en.wikipedia.org/wiki/Tourism in Indonesia From Wikipedia, the free encyclopedia.

${ }^{86}$ "Time for N. Maluku to become tourist destination". Retrieved 11 June 2015.

${ }^{87}$ Tourism in Indonesia https://en.wikipedia.org/wiki/Tourism in Indonesia From Wikipedia, the free encyclopedia.

DOI: 10.9790/5736-1005010119 $\quad$ www.iosrjournals.org 12 |Page
}


gains US $\$ 4.6$ billion of foreign exchange income annually. ${ }^{88}$ This makes tourism Indonesia's third most important non-oil-gas source of foreign revenue, after timber and textile products. ${ }^{89}$

After toppled Japan two years ago, China as the world's biggest tourism spenders now toppled Australia to become number three with $30.42 \%$ increase year-on-year, while totally foreign tourists growth by 10.6\% year-on-year set to more than 2.9 million. The top countries of origin is come from the AsiaPacific region, with Singapore 15.7\% Malaysia 14\% China 11\% Australia and Japan among the top countries of origin..$^{90}$ The United Kingdom, France, and Germany are the largest sources of European visitors. ${ }^{91}$ Although Dutch visitors are at least in part keen to explore the historical relationships, many European visitors are seeking the tropical weather at the beaches in Bali. Around 59\% of all visitors are travelling to Indonesia for holiday, while $38 \%$ for business purposes.$^{92}$ In 2012, according to the World Travel \& Tourism Council travel and tourism made a total contribution of $8.9 \%$ of GDP and supported $8 \%$ of total employment in Indonesia. ${ }^{93}$

\section{Tourist attraction in Indonesia}

In Indonesia, there are at least ten of tourist attraction such Borobudur and ancient temple, the diving sites, surfing, national parks, volcanoes, tourism of nature, cultural, urban and traditional culinary as follows :

\section{a. Borobudur Temple}

The single most visited tourist attractive in Indonesia is Borobudur. ${ }^{94}$ Both nature and culture are major components of Indonesian tourism. The natural heritage can boast a unique combination of a tropical climate, a vast archipelago of 17,508 islands, 6,000 of them being inhabited, ${ }^{95}$ the second longest shoreline in the world $(54,716 \mathrm{~km})$ after Canada. ${ }^{96}$ It is the world's largest and most populous country situated only on islands. ${ }^{97}$ The beaches in Bali, diving sites in Bunaken, Mount Bromo in East Java, Lake Toba and various national parks in Sumatra are just a few examples of popular scenic destinations. These natural attractions are complemented by a rich cultural heritage that reflects Indonesia's dynamic history and ethnic diversity. One fact that exemplifies this richness is that 719 living languages are used across the archipelago. ${ }^{98}$

The ancient Prambanan and Borobudur temples, Toraja, Yogyakarta, Minangkabau, and of course Bali, with its many Hindu festivities, are some of the popular destinations for cultural tourism. Tourism in Indonesia is currently overseen by the Indonesian Ministry of Tourism. ${ }^{99}$ International tourism campaigns have been focusing largely on its tropical destinations with white sand beaches, blue sky, and cultural attractions. Beach resorts and hotels have been developed in some popular tourist destinations, especially Bali island as the primary destination. At the same time, the integration of cultural affairs and tourism under the scope of the same ministry shows that cultural tourism is considered an integral part of Indonesia's tourism industry, and conversely, that tourism is used to promote and preserve the cultural heritage.

Some of the challenges Indonesia's tourism industry has to face include the development of infrastructure to support tourism across the sprawling archipelago, incursions of the industry into local traditions (adat), and the impact of tourism development on the life of local people. The tourism industry in Indonesia has also faced setbacks due to problems related to security. Since 2002, warnings have been issued by some countries over terrorist threats and ethnic as well as religious conflicts in some areas, significantly reducing the number of foreign visitors for a few years. However, the number of international tourists has bounced back positively since 2007 , and reached a new record in $2008,{ }^{100}$ and then made a new record every year and in 2014 set at 9,435,411 foreign tourists. ${ }^{101}$ In 2015, based on World Economic Forum survey, Indonesia got Travel and

\footnotetext{
88 "Visitor Arrivals to Indonesia 2000-2008" (Press release). Minister of Culture and Tourism, Republic of Indonesia. 2009. Retrieved 19 March 2009.

89 "Indonesia". The World Factbook. CIA. 2006. Retrieved 19 March 2010.

${ }_{90}$ Nadya Natahadibrata (3 June 2014). "Chinese tourists overtake Australian arrivals"

${ }^{91}$ "Visitor Arrivals to Indonesia by Nationality and Country of Residence Year 2005" (PDF) (Press release). Minister of Culture and Tourism. 2005.

${ }^{92}$ Indonesia Travel \& Tourism Economic Impact 2013. World Travel \& Tourism Council. Retrieved 11 November 2013

${ }_{93}$ Ibid.

${ }_{94}^{94}$ Mark Elliott ... (November 2003). Indonesia. Melbourne: Lonely Planet Publications Pty Ltd. pp. 211-215. ISBN 1-74059-154-2

95 "Indonesia". The World Factbook. CIA. 2006. Retrieved 19 March 2010

96 "Field Listing - Coastline". The World Factbook. CIA. 2006. Retrieved 19 March 2010

97 "Countries of the World by Area- no 16 Indonesia". Retrieved 19 September 2010

98 "Ethnologue - Languages of the World - Languages of Indonesia". Lewis, M. Paul (ed.). Ethnologue: Languages of the World, Sixteenth edition. Dallas, Tex.: SIL International. Online version. 2009. Retrieved 19 September 2010.

99 "Indonesian Ministry of Culture and Tourism". official website

100 "Visitor Arrivals to Indonesia 2000-2008" (Press release). Minister of Culture and Tourism, Republic of Indonesia. 2009. Retrieved 19 March 2009; Seehttp://web.pab-indonesia.com/content/view/11982/72/.

${ }^{101}$ Kadir, Abdul (December 2014). "Statistical Report on Visitor Arrivals to Indonesia 2014" (PDF). Ministry of Tourism of Republic Indonesia. Retrieved 9 September 2016. 
Tourism Competitiveness Index score 4.04 and rank at number 50, ${ }^{102}$ (up from number 70 in 2013, number 74 in 2011 and number 81 in 2009) from 141 countries. ${ }^{103}$ Aspects that need to be improved to move up the rank ladder are; tourism and ICT infrastructures, health and hygiene, environmental sustainability, and affinity for travel and tourism.

\section{b. Ancient Temples}

From the 4th century until the 15th century, Hinduism and Buddhism shaped the culture of Indonesia. Kingdom rise and fall, such as Medang Kingdom, Sriwijaya, Kediri, Singasari and Majapahit. Along the Indonesian classical history of Hindu-Buddhist era, they produced some temples and monuments called candi. The best-preserved Buddhist shrine, which was built during the Sailendra dynasty in the 8th century, is Borobudur temple in Central Java. A giant stone mandala stepped pyramid adorned with bell-shaped stupas, richly adorned with bas-reliefs telling the stories and teachings of Buddha.

A few kilometres to the southeast is the Prambanan complex, the largest Hindu temple in Indonesia built during the second Mataram dynasty? ${ }^{104}$ The Prambanan temple is dedicated to Trimurti; Shiva, Vishnu and Brahma, three highest gods in Hinduism. Both the Borobudur and the Prambanan temple compounds have been listed in the UNESCO World Heritage list since 1991. Both temple are the largest and the most popular, conveniently accessible from Yogyakarta, the heartland of Javanese culture. The Ramayana Javanese dance is performed routinely on the stage near Prambanan temple, provides the visitors the glimpse of Javanese classical culture.

Islam has also contributed greatly to the cultural society in Indonesia. As of 2006, 88\% of Indonesia's recorded population were Muslim. ${ }^{105}$ Islamic culture is prominent in Sumatra, and a few of the remaining sultanate palaces can be seen in Medan and Tanjung Pinang. The Islamic heritage tourism is also popular, especially among Indonesian Muslims and Muslims from neighbouring countries such as Malaysia, Singapore and Brunei that shared common Southeast Asian Islamic heritage. The activity usually linked with Islamic ziyarat pilgrimage to historical Islamic sites, such as historical mosques and tombs of venerated Islamic figures. However, for visitors in Islamic sites, either local or foreign, Muslim or non-Muslim, the rules of conduct and dress modesty is applied, such as removing the footwear while entering mosques or makam (tombs), visitor should not entering the site wearing shorts (sarong usually lent near the entrance to cover lower torso of the visitors), and wearing kerudung (head-dress covering) for women.

In Aceh the Baiturrahman Grand Mosque and tombs of Aceh Sultanate kings is popular destination, while in Medan the Medan Great Mosque and Maimun Palace is also major Islamic heritage destination. Most of Indonesian major cities have their own historical or monumental Grand Mosque (known Masjid Agung) that become city's landmark as well as tourism attraction. Istiqlal Mosque, Jakarta, the Indonesian national mosque and the largest in Southeast Asia is Jakarta's major landmark as well as tourist attraction. In Java the ziyarat pilgrimage is usually linked to historically important Islamic figures Nine Saints (known Wali Songo), they are important because of their historic role in the Spread of Islam in Indonesia. Their tombs and mosques scaterred along Java's north coast towns, such as Demak, Kudus, Cirebon, Gresik, to Ampel in Surabaya. The 15thcentury Agung Demak Mosque hailed as the first mosque established in Java. Menara Kudus Mosque is notable for incorporating Majapahit Hindu-Javanese architecture. The tomb of Sunan Gunungjati near Cirebon, is also the important ziyarat site in West Java. The heritage tourism might also focussed on the era of 17th- to 19thcentury royal Javanese courts of Yogyakarta Sultanate, Surakarta Sunanate and Mangkunegaran.

\section{c. The Famous Diving Sites}

Raja Ampat, is one of the world's richest marine biodiversity. With more than 17,508 islands, Indonesia presents ample diving opportunities. With $20 \%$ of the world's coral reefs, over 3,000 different species of fish and 600 coral species, deep water trenches, volcanic sea mounts, World War II wrecks, and an endless variety of macro life, scuba diving in Indonesia is both excellent and inexpensive. ${ }^{106}$ Bunaken National Marine Park (BNMP), at the northern tip of Sulawesi, claims to have seven times more genera of coral than Hawaii, ${ }^{107}$ and has more than $70 \%$ of all the known fish species of the Indo-Western Pacific. ${ }^{108}$ According to Conservation International (CI), marine surveys suggest that the marine life diversity in the Raja Ampat area is the highest

\footnotetext{
102 "Index Results-The Travel \& Tourism Competitiveness Index Ranking 2015v". World Economic Forum. Retrieved 25 August 2015.

103 Jennifer Blanke and Thea Chiesa. "The Travel \& Tourism Competitiveness Report 2013" (PDF). World Economic Forum. Retrieved 15 March 2014; "Infrastruktur Jadi Pengendala Pariwisata Indonesia". Pikiran Rakyat Online. Retrieved 11 June 2015

${ }^{104}$ Weiner, Eric (21 September 2008). "Living in Bali's Shadow, but Maybe Not for Long". The New York Times. Retrieved 25 May 2010

${ }^{105}$ Meidyatama Suryodiningrat. "Who are the Indonesian?". The Jakarta Post. Archived from the original on 19 July 2006. Retrieved 24 August 2006

106 "Scuba Diving in Indonesia: Komodo, Raja Ampat, Bali, Sulawesi and More". Retrieved 11 June 2015.

107 "North Sulawesi: Bunaken". Official Website of the North Sulawesi Tourism Promotion Board.

108 "Bunaken Diving Sites". Dive The World
}

DOI: $10.9790 / 5736-1005010119$

www.iosrjournals.org

14 |Page 
recorded on Earth. ${ }^{109}$ Moreover, there are over 3,500 species living in Indonesian waters, including sharks, dolphins, manta rays, turtles, morays, cuttlefish, octopus and scorpionfish, compared to 1,500 on the Great Barrier Reef and 600 in the Red Sea. ${ }^{110}$ Tulamben Bay in Bali boasts the wreck of the 120 metres US Army commissioned transport vessel, the Liberty. ${ }^{111}$ Other popular dive sites on Bali are at Candidasa and Menjangan. Across the Badung Strait from Bali, there are several popular dive sites on Nusa Lembongan and Nusa Penida. Lombok's three such as Gili Air, Gili Meno and Gili Trawangan are popular as is Bangka. Some of the most famous diving sites in Indonesia are also the most difficult to reach, with places like Biak off the coast of Papua and the Alor Archipelago among the popular, more remote, destinations for divers.

\section{d. Surfing in Indonesia.}

Surfing is also a popular water activity in Indonesia and the sites are recognized as world class. ${ }^{112}$ The well-known sports are mostly located on the southern, Indian Ocean side of Indonesia, for example, the large oceanic surf breaks on southern Java. However, the north coast does not receive the same surf from the Java Sea. Surf breaks can be found all the way along Sumatra, down to Nusa Tenggara, including Aceh, Bali, Banten in province, Lombok, the Mentawai Islands, and Sumbawa. Although Indonesia has many world-class surfing spots, the majority of surfers are came from abroad, especially Australia and United States. However, the seed of local surfing enthusiast began develop in Bali and West Java's Pelabuhan Ratu and Pangandaran beach, mostly came from nearby cities of Jakarta and Bandung. On Bali, there are about 33 surf spots, from West Bali to East Bali including four on the offshore island of Nusa Lembongan. In Sumbawa, Hu'u and Lakey Beach in Cempi Bay are popular surfing spots among surfing enthusiast. Sumatra is the second island, with the most number of surf spots, with 18 altogether. The common time for surfing is around May to September with the trade winds blowing from east to south-east. From October to April, winds tend to come from the west to northwest, so the east coast breaks get the offshore. Two well-known surf breaks in Indonesia are the G-Land in the Bay of Grajagan, East Java, and Lagundri Bay at the southern end of Nias island. G-Land was first identified in 1972, when a surfer saw the break from the window of a plane. Since 6 to 8 -foot (Hawaiian scale) waves were discovered by surfers at Lagundri Bay in 1975, the island has become famous for surfing worldwide.

\section{e. National Parks}

Bogor Botanical Gardens (BBG) established in 1817, and Cibodas Botanical Gardens established in 1862, are two among the oldest botanical gardens in Asia. With rich collections of tropical plants, these gardens are the center of botanical research as well as tourism attraction since colonial era. In Indonesia there are 50 national parks, of which six are World Heritage listed. The largest national parks in Sumatra are the 9,500square-kilometre Gunung Leuser National Park, the 13,750-square-kilometre, Kerinci Seblat National Park and the 3,568-square-kilometre, Bukit Barisan Selatan National Park, all three recognized as Tropical Rainforest Heritage of Sumatra on the UNESCO World Heritage list. Other national parks on the list are Lorentz National Park in Papua, Komodo National Park in the Lesser Sunda Islands, and Ujung Kulon National Park in the west of Java. To be noticed, different national parks offer different biodiversity, as the natural habitat in Indonesia is divided into two areas by the Wallace line.

The Wallaceabiogeographical distinction means the western part of Indonesia (Sumatra, Java, Kalimantan) have the same flora and fauna characteristics as the Asian continent, whilst the remaining eastern part of Indonesia has similarity with the Australian continent. ${ }^{113}$ Many native species such as Sumatran elephants, Sumatran tigers, Sumatran rhinoceros, Javan rhinoceros and orangutans are listed as endangered or critically endangered, and the remaining populations are found in national parks and other conservation areas. Sumatran orangutan can be visited in the Bukit Lawang conservation area, while the Bornean orangutan can be visited in Tanjung Puting national park, Central Kalimantan. The world's largest flower, rafflesia arnoldii, and the tallest flower, titan arum, can be found in Sumatra.

The east side of the Wallacea line offers the most remarkable, rarest, and exotic animals on earth. ${ }^{114}$ Birds-of-paradise, locally known as cendrawasih, are plumed birds that can be found among other fauna in Papua New Guinea. The largest bird in Papua is the flightless cassowary. One species of lizard, the Komodo

\footnotetext{
${ }^{109}$ Ultra Marine: In far eastern Indonesia, the Raja Ampat islands embrace a phenomenal coral wilderness, by David Doubilet, National Geographic, September 2007

110 "Scuba Diving Indonesia". Divesitedirectory

111 "Tulamben Bay: World Class Shipwreck Diving". Scuba Duba Doo.

112 "Pacific Islands Surf Spots \& Surfing Information - The Surfing Site". Retrieved 11 June 2015.

${ }_{113}$ Weiner, Eric (21 September 2008). "Living in Bali's Shadow, but Maybe Not for Long". The New York Times. Retrieved 25 May 2010. ${ }^{114}$ Whitten, Tony; et al. "Wallacea". Biodiversity International. Retrieved 17 September 2006

DOI: 10.9790/5736-1005010119 www.iosrjournals.org 15 |Page
}


dragon can easily be found on Komodo, located in the Nusa Tenggara lesser islands region. Besides Komodo island, this endangered species can also be found on the islands of Rinca, Padar and Flores ${ }^{115}$

\section{f. Volcanoes}

Hiking and camping in the mountains are popular adventure activities. Some mountains contain ridge rivers, offering rafting activity. Though volcanic mountains can be dangerous, they have become major tourist destinations. Several tourists have died on the slopes of Mount Rinjani, Indonesia's second highest volcano and a popular destination for climbers visiting Lombok in eastern Indonesia. Popular active volcanoes are the 2,329metre high Mount Bromo in the East Java province with its scenic volcanic desert around the crater, the upturned boat shaped Tangkuban Perahu and the volcanic crater Kawah Putih, north and south of Bandung respectively and both with drive-in access up to the crater, the most active volcano in Java, Mount Merapi near Yogyakarta, and the legendary Krakatau with its new caldera known as anak krakatau (the child of Krakatau). Gede Pangrango volcano in West Java is also a popular hiking destination, especially among domestic hikers.

In Sumbawa, Mount Tambora with its historical massive volcanic eruption back in 1815 that produced massive caldera also had gained attention among hikers. In neighboring island of Flores, the three-coloured volcanic crater-lake of Kelimutu is also hailed as one of Indonesia's natural wonder and had attracted visitors worldwide. Puncak Jaya in the Lorentz National Park, the highest mountain in Indonesia and one of the few mountains with ice caps at the (tropical) equator, ${ }^{116}$ offers the opportunity of rock climbing. In Sumatra, there are the remains of a super-volcano eruption that have created the landscape of Lake Tobaclose to Medan in North Sumatra.

\section{g. Nature Tourism}

Indonesia has a well-preserved, natural ecosystem with rainforests that stretch over about $57 \%$ of Indonesia's land, approximately $2 \%$ of which are mangrove systems. ${ }^{117}$ One reason why the natural ecosystem in Indonesia is still well-preserved is because only 6,000 islands out of 17,000 are permanently inhabited. Forests on Sumatra and Java are examples of popular tourist destinations. Moreover, Indonesia has one of longest coastlines in the world, measuring 54,716 kilometers, ${ }^{118}$ with a number of beaches and island resorts, such as those in southern Bali, Lombok ${ }^{119}$ Bintan and Nias Island. However, most of the well-preserved beaches are those in more isolated and less developed areas, such as Karimunjawa, the Togian Islands, and the Banda Islands.

\section{h. Cultural tourism}

Indonesia consists of 300 ethnic groups, spread over a 1.8 million $\mathrm{km}^{2}$ area of 6,000 inhabited islands. ${ }^{120}$ This creates a cultural diversity, further compounded by Hindu, Buddhist, Islamic and European colonialist influences. In Bali, where most of Indonesian Hindus live, cultural and religious festivals with Balinese dance-drama performances in Balinese temples are major attractions to foreign tourists.

Despite foreign influences, a diverse array of indigenous traditional cultures is still evident in Indonesia. The indigenous ethnic group of Toraja in South Sulawesi, which still has strong animistic beliefs, offers a unique cultural tradition, especially during funeral rituals. The Minangkabau ethnic group retain a unique matrilineal culture, despite being devoted Muslims. Other indigenous ethnic groups include the Asmat and Dani in Papua, the Dayak in Kalimantan and the Mentawai in Sumatra, where traditional rituals are still observed. Cultural tourism also plays a significant part in Yogyakarta, a special province in Indonesia known as centre of classical Javanese fine art and culture. ${ }^{121}$ The rise and fall of Buddhist, Hindu, and Islamic kingdoms in Central Java has transformed Yogyakarta into a melting pot of Indonesian culture.

Most major Indonesian cities have their state-owned museums, although most are in modest display. The most complete and comprehensive museum that displaying Indonesian culture and history spanned from prehistoric to colonial era is National Museum of Indonesia located in Jakarta. For Indonesian and foreign

\footnotetext{
115 "Komodo Dragon". Canadian Museum of Nature. Archived from the original on 2 September 2006. Retrieved 17 September 2006.

116 "Satellite Image Atlas of Glaciers of the World". Ian Allison, and James A. Peterson. U.S. Geological Survey, U.S. Department of the Interior (USGS). 18 November 2004. Retrieved 19 November 2010; "Observation and Mapping of the Glaciers Shown on Landsat ImagesPuncak Jaya and Ngga Pilimsit". Ian Allison, and James A. Peterson. U.S. Geological Survey, U.S. Department of the Interior (USGS). 18 November 2004. Retrieved 19 November 2010

117 "Indonesia". WWF UK. Retrieved 17 September 2006; Rainforest Action Network. Archived from the original on 8 September 2006. Retrieved 17 September 2006.

118 "Country Profile: Indonesia" (PDF) (Press release). Library of Congress. December 2004. Retrieved 23 June 2009

${ }^{119}$ Weiner, Eric (21 September 2008). "Living in Bali's Shadow, but Maybe Not for Long". The New York Times. Retrieved 25 May 2010.

120 "Indonesia". The World Factbook. CIA. 2006. Retrieved 19 March 2010

121 Timothy, Dallen J. (1998). "Cooperative Tourism Planning in a Developing Destination" (PDF). Journal of Sustainable Tourism. 6 (1): 52-68. doi:10.1080/09669589808667301. 
visitors unable to visit all Indonesian provinces, Taman Mini Indonesia Indah in East Jakarta provides a comprehensive microcosm of Indonesian culture. Established in 1975 by Tien Suharto, this park displaying museums, separate pavilions with the collections of Indonesian architecture, clothing, dances and traditions all depicted impeccably.

\section{i. Urban Tourism}

Urban tourism activities includes shopping, sightseeing in big cities, or enjoying modern amusement parks, resorts, spas, nightlife and entertainment. To some extent urban tourism might also involving municipal culture and heritage tourism, such as visits to city museums or parts of colonial old town. Ancol Dreamland with Dunia Fantasi theme park and Atlantis Water Adventure is Jakarta's answer to Disneyland-style amusement park and water park. Several similar theme parks also developed in other cities, such as Trans Studio Makassar and Trans Studio Bandung. The nation's capital, Jakarta, offers many places for shopping. Mal Kelapa Gading, the biggest one with 130 square kilometers, Plaza Senayan, Senayan City, Grand Indonesia, EX, and Plaza Indonesia are some of the shopping malls in the city. Next to high-end shopping centers with branded products, Indonesia is also a popular destination for handicraft shopping in the region. Certain Indonesian traditional crafts such as batik, songket, ikat weaving, embroidery, wooden statue and fashion products are popular souvenirs for visitors. Indonesian textile and fashion products are known for its good value; good quality with relatively cheap and reasonable price. Bandung is a popular shopping destination for fashion products among Malaysians and Singaporeans. ${ }^{122}$

Another popular tourist activity is golfing, a favourite sport among the upper class Indonesians and foreigners. Some notable golf courses in Jakarta are the Cengkareng Golf Club, located in the airport complex, and Pondok Indah Golf and Country Club. Bali has many shopping centres, for instance, the Kuta shopping centre and the Galeria Nusa Dua. Nightlife of Indonesia is also popular among foreigners, especially in the big cities like Jakarta, Bandung, Surabaya, Manado, Denpasar and Medan. ${ }^{123}$

\section{j. Culinary Traditions Tourism}

Indonesia has rich and diverse culinary traditions, and might be considered as one of the richest and the best in the world; such as rendang that recently voted as the number one dish of CNN International 'World's 50 Most Delicious Foods' list. ${ }^{124}$ Many regional cuisines exist, often based upon indigenous culture and foreign influences. ${ }^{125}$ Indonesian cuisine varies greatly by region and has many different influences. ${ }^{126}$ From succulent coconut-milk and curry rich Minangkabau cuisine to Oceanian seafood meal of Papuan and Ambonese cuisine. Embarked on a journey through Indonesian cuisine is as exciting as enjoying the diversity of Indonesian culture, as some kind of dishes might have myriad variations of different recipes across archipelago. Some popular Indonesian dishes such as nasi goreng, ${ }^{127}$ sate, ${ }^{128}$ and soto $^{129}$ are ubiquitous in the country and have numerous regional variations. These dishes are considered as Indonesian national dishes.

Eating establishments in Indonesia are available from the modest street-side cart vendors, to the luxury fine-dining restaurants. Most of malls and shopping centres in Indonesian major cities usually have an entire floor dedicated as a food courts, where one could samples rich variety of Indonesian cuisine, and some Indonesian cities have their own signature dishes. Such as Mie Aceh, Padang's rendang, Palembang's pempek, Jakarta's soto betawi and gado-gado, Bandung's siomay and batagor, Yogyakarta's guded, Solo' tongseng, Semarang's lumpia, Surabaya's rawon, Madura's satay, Balinese nasi campur and babi guling, Makassar's konro, Manado's tinutuan to Chinese Indonesian mie goreng. Some exhibitions, fairs and events often also incorporated eating experiences. Such as Jakarta Fair that offer local delicacies as well as food products from various corners of Indonesia, or Jakarta Fashion \& Food Festival (JFFF) that feature food and fashion.

\section{Conclusion}

\section{Conclusion And Recommendation}

Air transport industry and tourism are complemented each other. Tourism depends on transportation to bring visitors, in return the transportation industry depends on tourism to generate demand for its services. The improved facilities have stimulated tourism and the expansion of tourism has stimulated transport. In order to access the areas that are aimed, tourism will use any transportation mode. Air transport plays a dominant role in

122 "Malaysians flock to Bandung to shop". Retrieved 11 June 2015

${ }_{123}$ Bali Nightlife and Entertainment http://www.bali-indonesia.com/attractions/enternight.html

124 "World's 50 best foods: Readers' picks - CNN Travel". CNN Travel. Retrieved 11 June 2015

125 "Indonesian Cuisine." Epicurina.com. Accessed July 2011

126 "World's 50 best foods: Readers' picks - CNN Travel". CNN Travel. Retrieved 11; "Indonesian Cuisine." Epicurina.com. Accessed July 2011 ;"Indonesian food." Belindo.com. Accessed July 2011

127 "Nasi Goreng: Indonesia's mouthwatering national dish". Retrieved 5 July 2010

128 "Indonesian food recipes: Satay". Retrieved 5 July 2010

129 "A Soto Crawl". Eating Asia. Retrieved 5 July 2010.

DOI: $10.9790 / 5736-1005010119$

www.iosrjournals.org

17 |Page 
regional movements of tourists. Tourism makes, directly or indirectly, a major contribution to the global economy of State. In 2015, tourism contributed US\$ 2.2 trillion to world gross domestic product and provided over 108 million jobs globally. In Indonesia air transport has a significant role to contribute economy and creates jobs. Airlines, airport operators, airport on-site enterprises such as restaurants and retail, aircraft manufacturers and air navigations services provider employed 190.000 people.

\section{c. Recommendation}

Taking into consideration the growth of air transport and existing tourist attraction such Borobudur and ancient temple, the famous diving sites, surfing, national parks, volcanoes, nature tourism, cultural tourism, urban tourism, culinary tradition tourism, the authors recommend that the government of the Republic of Indonesia enhance both air transport and tourist industry to support the national economy in Indonesia.

\section{Bibliography}

[1]. LCJ Lehtonen, The Bilateral Air Transport Agreement of Finland: A Study in Public International Air Law, (LLM Thesis, McGill University Institute of Air and Space Law, 1977.

[2]. Martono and Amad Sudiro.,Current Air Transport Regulation in Indonesia (2013) XXXVIII Ann. Air \& Sp.L.at 55.

[3]. Michael Milde., Annals of Air and Space Law Vol.XVIII-1993-Part II. Toronto : The Carswell Company Ltd, 1993.

[4]. Paul Steven Dempsey., Annals of Air and Space Law, (2005) Vol. XXX-Part I. Toronto : The Carswell Company Ltd, 2005.

\section{Books}

\section{Articles}

[5]. Amad Sudiro and Martono K., National and International Air Transport Regulations in Indonesia. Vol.9(3) IOSR-JAC 8 (Mar.2016).

[6]. Martono and Amad Sudiro.,A Book Chapters: Aviation Laws and Regulations Applicable in Indonesia. Jakarta : Rajagrafindo, 2017 Chapter Five, page... harap dicari.

[7]. International Organization Science Research Journal (IOSR-JAC) Vol.9(3) 8(Mar.2016)

\section{Documents}

[8]. Act Concerning Civil Aviation, Act.No.15 Year 1992. State Gazette of the Republic of Indonesia no.53 Year 1992, Supplement State Gazette No.3481

[9]. Act Concerning Civil Aviation, Act No.1 Year 2009. State Gazette of the Republic of Indonesia No.1 Year 2009, Supplement State Gazette of the Republic of Indonesia No.4956.

[10]. Chicago Convention on International Civil Aviation, signed Chicago on 7 December 1944.

[11]. Government Regulation Concerning Change from State Enterprise (PN) Perhubungan Udara to Limited Company (PT) Garuda Indonesian Airways, Government Reg. No.67 Year 1971

[12]. Government Regulation Concerning Change from State Enterprise (PN) Perhubungan Udara Daerah dan Penerbangan Serba Guna "Merpati Nusantara" to Limited Liability Company (PT) Merpati Nusantara Airlines, Government Reg.70 Year 1971.

[13]. ICAO Doc.9228-C/1036 (1978) International Civil Aviation Organization's Standard Bilateral Tariff Clauses.

[14]. International Organization Science Research Journal (IOSR-JAC) Vol.9(3) 8(Mar.2016)

[15]. Ministerial Decree Concerning Garuda Indonesian Airways Permit from Jakarta to Medan, Padang, Palembang, Belitung, Teluk Betung, Kotaradja dan Bengkulu, Ministerial Decree No. T 4/4/4-U.

[16]. Ministerial Decree Concerning Routes Structure of PN Merpati Nusantara Airlines, Ministerial Decree No. S 8/2/5-Mphb (13 January 1969).

[17]. Ministerial Decree Concerning Home Bases of Airlines, Ministerial Decree No.SK 402/S/70 (30 December 1970).

[18]. Ministerial Decree Concerning Requirements and Provisions Regarding Commercial Use of Airplanes, Ministerial Decree No.SK 13/S/1971 (18 January 1971).

[19]. Ministerial Decree Concerning Domestic Tariff Changes, Ministerial Decree No.KM96/PR.303/Phb-84 ( 1 May 1984).

[20]. Ministerial Decree Concerning Engagement in Air Transport. Ministerial Decree No.KM 81(2004).

[21]. Ministerial Decree Concerning Engagement of Air Transportation, Ministerial Decree, KM 25 (25 November 2008.

[22]. Ministerial Decree Concerning the Calculation Mechanism and Determination of Ceiling Passengers for Economy Tariff Class of Air Transportation Domestic Services, Ministerial Decree No.26 (14 April 2010).

[23]. Regulation Concerning the Amount of Surcharges of Domestic Scheduled Transportation Tariffs, Ministerial Regulation No.PM 2 of 2014 (16 February 2014).

Others

[24]. "A Soto Crawl". Eating Asia. Retrieved 5 July 2010.

[25]. Air Born Indonesia, Eastindo, Gatari Air Services, Mimika Air, Nusantara Air Charter, Nusantara Buana Air, Premiair and transwista Prima Aviation;

[26]. https://en.wikipedia.org/wiki/List_of_airlines_of_Indonesia

[27]. AIR TRANSPORTATION http://www.indonesia-tourism.com/transport.html.

[28]. Bali Nightlife and Entertainment http://www.bali-indonesia.com/attractions/enternight.html

[29]. "Bunaken Diving Sites". Dive The World

[30]. "Countries of the World by Area- no 16 Indonesia". Retrieved 19 September 2010

[31]. "Country Profile: Indonesia" (PDF) (Press release). Library of Congress. December 2004. Retrieved 23 June 2009

[32]. Claire Harvey (5 May 2002). "'Kuta Cowboys' strutting their stuff for lovelorn visitors". The Jakarta Post. Retrieved 16 October 2014;

[33]. Dieny Ferbianty. "Sejarah Pariwisata Indonesia" (PDF). Retrieved 27 June 2011

[34]. Elliot, Mark (November 2003). Indonesia. Lonely Planet. ISBN 1-74059-154-2

[35]. "Ethnologue - Languages of the World - Languages of Indonesia". Lewis, M. Paul (ed.). Ethnologue: Languages of the World, Sixteenth edition. Dallas, Tex.: SIL International. Online version. 2009. Retrieved 19 September 2010.

[36]. "Field Listing - Coastline". The World Factbook. CIA. 2006. Retrieved 19 March 2010 
[37]. http://www.airports.org/aci/aci/file/ADN\%20-\%20Momberger/ACI-ADN\%20Dec\%202005.pdf; New Lombok International Airport, The Directorate General of Air Communication, and PT. (Persero) Angkasa Pura 1, Project Summary, Jakarta, 4 January 2005.

[38]. http://aviationbenefits.org/social-development/tourism/

[39]. https://www.garuda-indonesia.com/id/en/destination/route-map/index.page

[40]. http://www.indonesia-tourism.com/transport.html

[41]. IATA ,Economics., The Air Transport Sector Makes a Major Contribution to the Indonesian Economy

[42]. "Index Results-The Travel \& Tourism Competitiveness Index Ranking 2015v". World Economic Forum. Retrieved 25 August 2015.

[43]. Indonesia Air Asia., https://en.wikipedia.org/wiki/Indonesia_AirAsia From Wikipedia, the free encyclopedia.

[44]. "Indonesian Cuisine." Epicurina.com. Accessed July 2011

[45]. "Indonesian Ministry of Culture and Tourism". official website

[46]. "Indonesia". The World Factbook. CIA. 2006. Retrieved 19 March 2010

[47]. Indonesia Travel \& Tourism Economic Impact 2013. World Travel \& Tourism Council. Retrieved 11 November 2013

[48]. Indonesia Aviation: Outlook 2010, published by Indonesian National Air Carrier Association. Jakarta: 2010.

[49]. Indonesia Investments. "2013's Growing Number of Tourists in Indonesia Meets Government Target". Retrieved 11 June 2015.

[50]. "Indonesia". WWF UK. Retrieved 17 September 2006; Rainforest Action Network. Archived from the original on 8 September 2006. Retrieved 17 September 2006.

[51]. "Indonesia". The World Factbook. CIA. 2006. Retrieved 19 March 2010.

[52]. Jennifer Blanke and Thea Chiesa. "The Travel \& Tourism Competitiveness Report 2013" (PDF). World Economic Forum. Retrieved 15 March 2014; "Infrastruktur Jadi Pengendala Pariwisata Indonesia". Pikiran Rakyat Online. Retrieved 11 June 2015

[53]. Kadir, Abdul (December 2014). "Statistical Report on Visitor Arrivals to Indonesia 2014" (PDF). Ministry of Tourism of Republic Indonesia. Retrieved 9 September 2016.

[54]. Runway Aviation News : Deregulasi Penerbangan Indonesia Dan Akibatnya https://web.archive.org/web/20151222111416/http://www.runway-aviation.com/deregulasi-penerbangan-indonesia-dan-akibatnya/ 31 January 2015.

[55]. http://divezone.net/travel/komodo-island

[56]. https://www.garuda-indonesia.com/id/en/destination/route-map/index.page

[57]. http://www.thejakartapost.com/news/2016/09/06/government-prioritizes-tourism-development-10-regions.html .

[58]. https://en.wikipedia.org/wiki/Sriwijaya_Air_destinations From Wikipedia, the free encyclopedia

[59]. https://en.wikipedia.org/wiki/List_of_airlines_of_Indonesia access on 4/9/2017

[60]. http://www.indonesia-tourism.com/north-sumatra/toba_lake.html

[61]. https://en.wikipedia.org/wiki/Tourism_in_Indonesia From Wikipedia, the free encyclopedia.

[62]. "Komodo Dragon". Canadian Museum of Nature. Archived from the original on 2 September 2006. Retrieved 17 September 2006.

[63]. "Malaysians flock to Bandung to shop". Retrieved 11 June 2015

[64]. Mark Elliott ... (November 2003). Indonesia. Melbourne: Lonely Planet Publications Pty Ltd. pp. 211-215. ISBN 1-74059-154-2

[65]. Meidyatama Suryodiningrat. "Who are the Indonesian?". The Jakarta Post. Archived from the original on 19 July 2006. Retrieved 24 August 2006

[66]. Nadya Natahadibrata (3 June 2014). "Chinese tourists overtake Australian arrivals"

[67]. "North Sulawesi: Bunaken". Official Website of the North Sulawesi Tourism Promotion Board.

[68]. "Scuba Diving in Indonesia: Komodo, Raja Ampat, Bali, Sulawesi and More". Retrieved 11 June 2015.

[69]. "Nasi Goreng: Indonesia's mouthwatering national dish". Retrieved 5 July 2010

[70]. "Surpassing 2010 target, RI aims to lure 7.7 mln tourists". Retrieved 11 June 2015); Tourism in Indonesia

[71]. $\quad$ "Pacific Islands Surf Spots \& Surfing Information - The Surfing Site". Retrieved 11 June 2015.

[72]. Weiner, Eric (21 September 2008). "Living in Bali's Shadow, but Maybe Not for Long". The New York Times. Retrieved 25 May 2010

[73]. PRESS RELEASES., Indonesia's Wings Air to become the largest ATR operator with 60 aircraft. http://www.atraircraft.com/newsroom/press-releases-details-1175-en.html 16 February 2012 Access on 4/9/2017

[74]. Robert Cribb, 'International tourism in Java, 1900-1930, South East Asian Research 3 no 2 (1995), pp. 193-204. ISSN 0967-828X.

[75]. "Satellite Image Atlas of Glaciers of the World". Ian Allison, and James A. Peterson. U.S. Geological Survey, U.S. Department of the Interior (USGS). 18 November 2004. Retrieved 19 November 2010; "Observation and Mapping of the Glaciers Shown on Landsat Images-Puncak Jaya and Ngga Pilimsit". Ian Allison, and James A. Peterson. U.S. Geological Survey, U.S. Department of the Interior (USGS). 18 November 2004. Retrieved 19 November 2010

[76]. Timothy, Dallen J. (1998). "Cooperative Tourism Planning in a Developing Destination" (PDF). Journal of Sustainable Tourism. 6 (1): 52-68. doi:10.1080/09669589808667301.

[77]. Tourism in Indonesia https://en.wikipedia.org/wiki/Tourism_in_Indonesia From Wikipedia, the free encyclopedia.

[78]. "Time for N. Maluku to become tourist destination". Retrieved 11 June 2015.

[79]. "Visitor Arrivals to Indonesia 2000-2008" (Press release). Minister of Culture and Tourism, Republic of Indonesia. 2009. Retrieved 19 March 2009.

[80]. http://web.pab-indonesia.com/content/view/11982/72/ .

[81]. Travel and Tourism Competitiveness Report 2015 - Indonesia". weforum.org. Retrieved 25 September 2016; Tourism in Indonesia https://en.wikipedia.org/wiki/Tourism_in_Indonesia From Wikipedia, the free encyclopedia.

[82]. "Tulamben Bay: World Class Shipwreck Diving". Scuba Duba Doo.

[83]. Weiner, Eric (21 September 2008). "Living in Bali's Shadow, but Maybe Not for Long". The New York Times. Retrieved 25 May 2010

[84]. "World's 50 best foods: Readers' picks - CNN Travel". CNN Travel. Retrieved 11 June 2015

[85]. Welcome INDONESIA, WONDEFUL INDONESIA.

[86]. Whitten, Tony; et al. "Wallacea". Biodiversity International. Retrieved 17 September 2006

[87]. Robert Cribb, 'International tourism in Java, 1900-1930, South East Asian Research 3 no 2 (1995), pp. 193-204. ISSN 0967-828X. 